\title{
JULIUS MÄGISTE EESTI INGERI LÄÄNEMERESOOME MURRETE UURIJANA*
}

EVA SAAR

J ulius Mägiste 115. sünniaastapäev olgu paslikuks hetkeks, mil meenutada tema panust praeguseks juba kadunud keelekujude uurimisse ja talletamisse.

Julius $^{1}$ Gustavi p Mägiste sündis 19. XII 1900 Tartumaal Kudina valla Kassema külas talupidaja pojana. Astunud ülikooli 1919. aastal, kaitses Mägiste magistriväitekirja „Rosona (Eesti Ingeri) murde pääjooned” veebruaris 1923, sooritas suulise doktorieksami novembris 1924. Septembrist 1925 kuni 1929. aasta maini pidas Mägiste Tartu Ülikoolis õppeülesande täitjana loenguid ja seminare läänemeresoome keelte alal. Doktorikraadi sai ta 1928. aastal ilmunud väitekirja „oi-, e $i$-deminutiivid läänemeresoome keelis. Läänemeresoome nominaaltuletus I" eest. Märtsis 1929 valiti ta läänemeresoome keelte erakorraliseks professoriks, aprillis 1932 samas korraliseks professoriks. 1941. aasta algusest oli ta Tartu Riikliku Ülikooli soome-ugri keelte kateedrijuhataja ja professori kohusetäitja (Mägiste f 52: 1-2). 1944. aastal põgenes ta Saksamaa kaudu Rootsi, kus jätkas õpetlase ja teadlasena ülikoolilinnas Lundis. Julius Mägiste suri 1978. aastal.

Alljärgnevas leiavad meenutamist Mägiste Eesti Ingeri alased uurimused, mis valmisid tema sulest noore mehena teadlastee alguses. Toetudes Mägiste enese kirjeldusele toonastest oludest, kirjeldatakse põgusalt, milline oli Eesti Ingeri eluolu 1920. aastate alguses. Arutletakse isurite ja isuri keele nimetamise ümber, samuti tuuakse arhiivi varamutest lugejani vanemate kolleegide hinnangud Mägiste tegevusele ajast, mil ta valiti vaid 28-aastasena läänemeresoome keelte erakorraliseks professoriks.

\section{Eesti Ingeri, nimetatud ka Viru Ingeri - mis maa see on?}

Ingerimaa on ajalooline piirkond, mis hõlmab maa-ala Soome lahe lõunarannikul Narva jõest läänes kuni Laadoga järveni idas, haarates põhjas enda alla ka Karjala kannase. Ingerimaa põlised rahvad on vadjalased ja isurid, peale Stolbovo rahu XVII sajandi algul on piirkonda asunud ka hulgaliselt soomlasi.

Ingerimaa kõige läänepoolsem osa, Narva jõe paremkalda ala sai ametlikult Eesti Vabariigi osaks Tartu rahulepinguga 2. veebruaril 1920. Tiit Rosenbergi andmeil oli Eesti Ingeris 1922. aastal 7608 elanikku, mis püsis enamvähem samas suurusjärgus ka 1934. aastal. Piirkond kuulus Eesti tihedaima asustusega alade hulka. Etniliselt oli juba sel perioodil tegemist valdavalt vene rahvastikuga: Naroova (Narva) vallas $\left(173 \mathrm{~km}^{2}\right)$ oli 2799 elanikku, neist

* Artikkel põhineb 4. juulil 2015 Julius Mägiste sünnikohas Kassema külapäeval peetud ettekandel.

${ }^{1}$ Mägiste ise tavatses sageli oma eesnime kirjutada kujul Juulius (vt nt Mägiste f 52). 
venelasi $63 \%$, ingerlasi $24 \%$ (672 inimest) ja eestlasi $13 \%$ (364 inimest); Kose (Piiri) vallas $\left(91 \mathrm{~km}^{2}\right) 1310$ elanikku, neist venelasi $91 \%$ ja eestlasi ligi $9 \%$; Skarjatina (Raja) vallas $\left(111 \mathrm{~km}^{2}\right) 3499$ elanikku, neist venelasi $96 \%$ ja eestlasi $3 \%$ (Rosenberg 2013: 129).

Tegelikkuses on täpset rahvastiku koosseisu tolleaegsete dokumentide põhjal raske hinnata, sest n-ö segavaks üldnimetuseks on ingerlased, kelle all enamasti mõistetakse soomlasi. Ülaltoodud rahvastiku jaotusest ei selgu aga, kas piirkonnas elavad isurid on arvatud venelasteks või ingerlasteks - ei saa välistada, et osa piirkonnas juba venestunud õigeusklikest isuritest oli ametlikult kirja pandud venelastena. Isurid olid sajanditaguse aja kirjasõnas nagu hea laps, kel mitu nime: ingerikud, ingrikud, isurlased, Ingeri karjalased, isurid.

Mägistel lipsab rahva nimetus isur „üle huulte” tegelikult juba aastal 1923. aastal kaitstud ja 1925. aastal ilmunud magistritöö „Rosona (Eesti Ingeri) murde pääjooned” eessõnas (Mägiste 1925: VII). Sessamas töös jaotab ta edaspidi rahvused usu järgi: soomlased - luterlased, kreeka-katoliku usku ingrikud ehk isurid, aga ka isurlased. Soome keeleteaduses ei peetud tol ajal - ilmselt Volmari Porkka (1885) doktoritööst lähtunud arusaamade kohaselt - isuri keelt eraldi läänemeresoome keeleks, vaid arvati soome murrete hulka (sm inkeroismurteet). Mägiste doktoritöös on Rosona piirkonna murded (lühendatuna ingRos) arvatud soome keele alla (Mägiste 1928: 58-131), seevastu ülejäänud isuri keeleala näited leiab karjala-aunuse-lüüdi keelerühma alt nimetusega Ingeri (karjala) murre (lühendatuna karjIng) (Mägiste 1928: 132-172), magistriväitekirjas aga nimetatakse ülejäänud isuri keeleala SiseIngeriks (Mägiste 1925: 93).

Ka noore vabariigi ajakirjandus ning ametnikud ei olnud Eesti Ingeri rahvaste nimetamisel kuigi järjepidevad, see ilmneb näiteks perekonnanimede paneku kajastamisest. Sarnaselt Tartu rahulepingu alusel ühendatud Petserimaaga puudusid ka Ingerimaa õigeusklikel elanikel XX sajandi algul üldjuhul perekonnanimed, liidetud idaalade elanikel oli kasutusel vaid ees- ja isanimi. Eesti Vabariigi seadusandlus kohustas kodanikke võtma endale perekonnanimed kuni 1. jaanuarini 1922, nimede panekuks moodustati lausa vastavad komisjonid (vt Käokuld...). 13. VIII 1923 Postimees teatab, et Naroova vallas on vabatahtlikult omale perekonnanimed võtnud 949 ingerlast ja 67 venelast, kes võtsid omale vastavalt 175 eesti-, 46 ingeri-, 15 soome- ja 131 venekeelset perekonnanime (Sommer 1923: 4). Sellistest ajaleheteadetest järeldub, et ingerlaste seas oli nii ingeri- (sic!) kui ka soomekeelseid elanikke.

\section{Mägiste Ingerimaal 1920. aastatel}

Mägiste kõige tähtsamaks ja tänase päevani tsiteeritavaks uurimuseks Eesti Ingeri keelte alal on jäänud magistriväitekiri „Rosona (Eesti Ingeri) murde pääjooned” (1925). Uurimuse jaoks kogus Mägiste Eesti Ingeris välitöödel materjali 1922. aastal noore mehena, Emakeele Seltsi stipendiaadina ja hiljemini täiendavalt 1923. aasta kevadel ning sama aasta augusti esimesel poolel. Ülevaate oma esimesest „Reisust Eesti Ingeris” ja Eesti Ingeri, täpsemalt toonase Naroova valla soome sugu elanikkude asujastikust leiab Õpetatud Eesti Seltsis peetud ettekande põhjal ajakirjas Eesti Keel 1922. aastal avaldatud artiklist (Mägiste 1922), mis on ühtlasi esimene Mägistelt trükis ilmunud kirjutis. 
Mägiste kui keelehuvilise noore teadlase hinnang piirkonna rahvastiku koosseisu osas on järgmine (Mägiste 1922: 156-157): 1) umbes 800 luteriusulist soomlast, 2) vähe üle 1000 enamasti venestunud õigeusulise nn isurlase, 4) umbes 400 eestlast ja 5) umbes 300 venelast. Loetelust on välja ununenud number 3 - kas võiksime loota, et see oleks tähistanud vadjalasi? Samuti tundub - võrreldes ülal esitatud ametlike andmetega - ootamatult väike venelaste arv.

Mägiste reisikirjelduse vahendusel saab lugeja kujuka pildi kohalikest oludest, haridus- ja kultuurielust (Mägiste 1922: 158): „Endine Peterburi kubermangu osa, endiseil aegadel venelasist kubisenud Narva ja N.-Jõesuu külje all, vene külade naabruses on soomekeelnegi osa Naroova vallast vene kulturi heast ja halvast osa saanud, rahvusliku iseolemise kaotamisele mõistetud olnud. Siin kõrvuti elavaid õigeusulisi ja luteriusulisi soomlasi võrreldes paistab alles silma, kui tähtsat osa on etendanud selles kirik. Õigeusulised on põhjalikult venestumas, vähemalt puht veneusulisis külis Väikülas ja Saarkülas, kuna mujal - Hanikel, Vanakülas j. m. - kus nad elavad luterlastega segi, nad olles viimaste tugeva mõju all edukalt on vastu pannud venestumisele." Üldiselt oskavad nooremad põlvkonnad kõik soravalt vene keelt kõnelda. „Niisuguse olukorra on loonud, rääkimata kirikust, umbvenekeelsed koolid, mille võimsaks täienduseks on olnud õnnetu kodune venekeele õpetamine lapsile koolitöö hõlbustamiseks ..., ja segaabielud" (Mägiste 1922: 158).

Mägiste paneb teraselt tähele ka suhtumist kõneldavasse keelesse: „Kuid nüüd tundub vene keel enam omana, ja soome murre on kui miski soovimatu Jumala vits: pask kiel (halb keel), lamba(a)n kiel (lamba keel), sest et tihti tarvitatav männä 'minna' verb esineb ajalooliselt arenenuna mään 'lähen', määd 'lähed' etc. kujul, ja seistakse kui mõistatuse ees, kust säärane õnnetus venelasile kaela on tulnud, kui öeldakse: vennä(ä)n usko(o) rissittü, a lamba(an) kieldä lägäjöd 'vene usku ristitud, kuid kõnelevad lamba keelt', kuid lahti temast ei saada" (Mägiste 1922: 158).

Oma esimesel pikemal murdekogumisretkel sai Mägiste näha ja kogeda kõiki välitööde tegijate rõõme ja vaevasid. Nii näiteks oli temast esiotsa lausa kõrvale hoitud, pidades teda spiooniks või salapolitsei agendiks. Millega aga Mägistel vedas, see oli keelejuhtide leidmine. Nii näiteks töötas ta Kalliviere külas ühe lahke lesknaisega harilikult 8-10, harvem 6 tundi päevas (Mägiste 1922: 161). Kogumistöö tulemusena kogunes „...1600 sõnalehte, millest suurel osal on enam kui üks sõna, nimelt muid samajuurelisi või tihti sünonümegi. Säärast teguviisi olin sunnitud tarvitusele võtma, kuna olin kaasa võtnud ettenägemata vähe sõnalehti" (Mägiste 1922: 162).

Keeleandmete kogumisel pööras Mägiste tähelepanu häälikuloolistele materjalidele, sõnavarale, kohanimedele, folkloorsetele ja olustikulistele tekstidele. Kõnesoleva magistriväitekirja trükiversiooni lisaks on ka Eesti Ingerist kogutud mõistatused: 69 soome, 14 isuri oma (vt Mägiste 1925: 125-128).

\section{Mõni sõna Mägiste magistritöös käsitletavate keelekujude kohta}

Uurimuse „esemeks” - nagu Mägiste ise väljendus - oli kaheks alamurdeks jagunev keelepruuk: kreeka-katoliku usku ingrikud e isurid ja soomlasedluterlased. „Luterlaste ainestik põhineb peamiselt Kalliviere külast (täiendatud Kullaküla materjaliga), kuna kreeka-katoliiklaste murde esituse aluseks 
on Väiküla, eriedustuse korral on mainitud kr.-kat. Vanaküla andmed (ka Saarküla ja Hanikeküla)" (Mägiste 1925: VII-VIII). Ehk siis - ühe Rosona murde uurimus kätkeb endas tegelikkuses kahe erineva keelevariandi häälikuloolist ülevaadet.

Mõlemad Mägiste magistriväitekirjas käsitletud keelekujud hõlmavad endas läänemeresoome murrete kontiinumil erineva ja erilise „komplekti” keelelisi nähtusi. Kindlalt saab väita, et sellise koostisega keelekujusid tänapäeval me kahjuks enam ei kuule. On tänuväärne, et Mägiste on registreerinud äärmise täpsusega toonased sealsed häälikuloolised nähtused, millest osad viitavad rohkem soome keele, teised isuri-karjala suunda, aga tuttavat on palju ka eestlase kõrva jaoks, olgu selleks kas või pikad vokaalid aa ja ää, mis soome idamurretes ja karjala keeles on diftongistunud.

Luterlaste ja kreeka-katoliiklaste keelepruuk erineb näiteks järgmiste häälikulooliste joonte poolest:

1. Kreeka-katoliku keelepruugis on astmevaheldus arenenud kaugemale kui luterlastel, vrd nt luterlastel NSg kätküt 'kätki', kreeka-katolikel NSg kätüt 'kätki', ehkki selles osas on varieerumist mõlemal poolel, mis tuleneb „murdesegunemisist”. Ka häälikuühendite $s k$ ja $h k$ kohatise vaheldumise (muhku : muhun; pehko : pehost 'põõsas' jne) luterlaste keeles tahaks Mägiste panna „...kr.-kat. naabermurde arvele, kus nad on kodusemad. [---] Praeguse olukorra kirevus seletub kr.-katoliiklaste murde mõjuga, mis on suurendanud k-kaduliste juhuste arvu," kirjutab Mägiste (1925: 27).

2. Kreeka-katoliku keelepruugi eripärasusteks on sõnasisesed helilised klusiilid hilistes vene laensõnades, nt as sie pagana 'ah sa pagan', truba 'korsten'; omapärane, et helilistena on nad võinud esineda ka geminaatide ehk kaksikkonsonantidena: PSg flaggū 'lippu', IllSg saddā'(läks) aeda' (Mägiste 1925: 6).

3. Luterlastel on kaura 'kaer', nauran 'naeran' (Mägiste 1925: lk 12), kreeka-katoliiklased on säilitanud samad sõnad kujul kagra, nagran, lisaks on helilise kaashääliku ees ka klusiil heliline: niegla 'nõel', adra 'ader' (Mägiste 1925: lk 14-15).

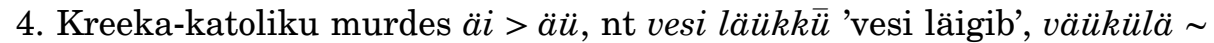
väikülä (Mägiste 1925: 77).

5. Sisekao juhtumid kreeka-katoliku murdes, nt NSg kandla 'kannel', angre 'angerjas' (Mägiste 1925: 8).

Loetelu võiks jätkata. Ehkki Mägiste ei käsitle magistritöös eraldi vormiõpetust, paistab keelenäidetest ometi silma, et Eesti Ingeri on eesti keelele sarnase kaasaütleva keele ala, nt vipuyka (kaivO) 'vibuga (kaev)', kässīykä 'kätega' (Mägiste 1925: 34, 42). Isuri keele teistes murretes kasutatakse sel puhul kaassõna kera, nt Soikola ja Hevaha murdes kässīn kera 'kätega'. Häälikuloo kaudu saab vormistiku kohta muudki teada, nt *-p $(i)$ säilimine kaasrõhulise silbi järel oleviku ainsuse 3. isiku moodustamisel kreeka-katoliku murdes, nt pillahup 'viskub, loksub (üle)' (Mägiste 1925: 7), vrd luterlaste murjah $\bar{u}$ 'kortsub' (Mägiste 1925: 5). Isuripärased ehk $a$-lõpulised on piirkonnas tarvitatavad mitmuse 1. ja 2. isiku lõpud: parensimma 'parandasime', otitta 'võtsite' (Mägiste 1925: 77) (vrd sm -mme, -tte). 


\section{Kaasteeliste hinnanguid Mägiste magistritöö kohta}

Kui sageli juhtub, et teadlase töö väärtust hakatakse hindama alles pärast tema siitilmast lahkumist, siis Mägiste teaduslikku tegevust tõsteti esile juba tema varases nooruses teadlastee alguses. Olude sunnil valiti ta pärast Lauri Kettuse Tartust professoriametist lahkumist vaid 28 -aastasena läänemeresoome keelte erakorraliseks professoriks. Sellesse ametisse valimise ajast pärit soovituskirjadest, mida säilitatakse Tartu Ülikooli Raamatukogu käsikirjakogus Mägiste isikuarhiivis (fond 52), saab lugeda Mägiste vanemate kolleegide hinnanguid tema teaduslikule tegevusele, sh magistriväitekirjale.

Mägiste kunagine õppejõud ja juhendaja Lauri Kettunen kirjutab Tartu Ülikooli filosoofiateaduskonnale 10. I 1929 Mägiste erakorraliseks professoriks valimise eel saadetud retsensioonis (Mägiste f 52: 11) „Rosona murde pääjoonte” kohta järgmist: „Dr. Mägiste esimene suurem uurimus, mis üle saja leheküljeline „Rosona murde pääjooned” (Tartu 1925) on kaugelt rohkem kui harilik laudatur-töö, millised Soomes on avaldatud nii mitugi kohalikkude murrete üle. On juba väga tähtis, et seni peaaegu tundmatu Lääne-Ingeri, niihästi soomlaste kui karjalaste (või karjala värviline soome) murre nüüd kiiduväärilise põhjalikkusega häälikulisest küljest on valgustatud, aga sääljuures on noor autor mahti saanud ka näidata, et ta mõistab ainet metoodiliselt käsitada... nende kahe sugulusmurde iseäraldus on juba autorit sundinud võrdlemisi iseseisva võttega oma ainele liginema."

Uurali keelte professor Julius Mark tõdeb samade valimiste puhul 3. III 1929 magistriväitekirja osas: „Kuna aga siin kahe erineva murdega tegemist on, edasi kokkupuutumistega teiste keeltega, üheltpoolt vene, teiseltpoolt eesti keelega, on ainestik seega kirevusega pakkunud rohkesti võimalusi iseseisvate järelduste tegemiseks, millega autor on laitmata hakkama saanud. On näha, et autor ainestikku hästi tunneb, samuti vastava kirjandusega hästi tuttav on. Mõningate puuduste peale vaatamata, millest küll ühtki eriti mõjuvat ei ole, nõuab see töö kõigiti tunnustust" (Mägiste f 52: 11).

Julius Mark hindab Mägiste puhul samuti: „...sügavat ja põhjalikku läänemeresoome keelte tundmist, head kombineerimisoskust ja head meetodi [tundmist/valdamist]. Olles silmapaistvalt andekas, omandades kõik eeldused keeleteaduse alal töötamiseks (ajaloolisvõrdleva vaatlusviisi ning nõutava täpsuse) ja elava huvi oma ala vastu, on ta suure andumise ja püsivusega töötanud algusest peale oma teadmiste laiendamiseks ja süvendamiseks. Dr. Mägiste ei ole juhuslikult saanud keeleteadlaseks, vaid teda on juhtinud tema kalduvused ja anne" (Mägiste f 52: 13).

Eesti keele professor Andrus Saareste iseloomustab 12. III 1929 retsensioonis Mägistet nõnda: „Tema seni ilmunud teaduslikud tööd on osutanud kiiduväärt põhjalikkust ja erksat teaduslikku vastutustunnet. Eriliselt meeldivaks jooneks tema avaldatud uurimustes on objektiivsus ja asjalikkus ning õiglus teiste kaasuurijate vaadete ja tulemuste hindamisel” (Mägiste f 52: 13-14). 


\section{Kadunud käsikiri}

Mägiste teadis ja oskas ka ise objektiivselt hinnata oma teadustööde väärtust. Nii kirjutab ta 1937. aastal ajakirjas Looming ilmunud artiklis „Rahvuslike teaduste edust Eestis”: „...Spetsiaalselt eesti ligemate sugukeelte kohta Eestis ilmund töist väärivad esiletõstmist põhjapanev teos lõuna-vepsa häälikuteloost ja (foneetilise sissejuhatusega varustet) liivi tekstidekogu (Kettunen), arvesse võiksid tulla ka vadja vanimate keele-mälestusmärkide publikatsioon ja tekstidekogu (Ariste), Eesti ingeri murde häälikuteloo esitus, lühiuurimus kreevin-vadjalaste keelest ja (trükki minev) Eesti ja Vene ingeri tekstidekogu (Mägiste)" (Mägiste 1937: 481).

Kui ei oleks olnud Teist maailmasõda, oleksid paljud asjad maailmas iseendast mõista teisiti. Sõda põhjustab ja tähendab alati segadust, kadu, hävingut. Üheks suureks sõjaohvriks Eesti Ingeri keelematerjali kogumise kontekstis on Mägiste käsikiri „Lääne-Ingeri tekste sõnastikuga”, mis oli ometi trükivalmina (250 lehekülge!) antud riiklikule kirjastusele Teaduslik Kirjandus. Need andmed pärinevad Mägiste enda kirjutatud eluloost ja teadustööde nimestikust, mis ta esitas Tartu Riikliku Ülikooli kõrgemale atesteerimiskomisjonile veebruaris 1941 (Mägiste f 52).

Kolmkümmend aastat hiljem, Ruben Erik Nirvi „Inkeroismurteiden sanakirja” (1971) ilmumise puhul mainib Mägiste ajakirjas Virittäjä, kirjutades sõnastiku koostamise lähteallikatest, kahetsusega: „Koostaja on teinud kõik, et saada sõnaraamatut nii esinduslikuks, nagu see nüüd on. Akadeemilise Emakeele Seltsi kogudes oli 1930. aastatel teatud määral käsitsi kirjutatud ja minu kogutud keeleainest Alam-Luuga murdealalt (Väikülast, Vanakülast, ka Pärspäält), mille säilimisest praeguse aja Eestis ei ole teateid. Kaduma on läinud ka Ida-Saksamaale jõudnud käsikirjas Lääne-Ingeri isurikeelsed tekstid [inkerikkotekstit], mõnisada lehekülge, mida „asjatundjad” ei julgenud avaldada, aga millest nüüd oleks Nirvile [sõnaraamatu koostamise juures] kasu olnud..." (Mägiste 1972: 476).

Julius Mägiste poeg Juhan Mägiste meenutas 2015. aasta suvel Kassemal käsikirjade kadumisega seoses, et sõja jalust põgenemisel kasutas Mägiste pere kohvrite, kus oli muuhulgas ka Ingeri tekstikogu käsikiri, transportimiseks edasiliikumisel käru. Et aga Mägiste tütar oli haige ning ei suutnud jalgsi kõndida, otsustati kärusse panna hoopis laps ning kohvrid anti kogu sisuga ühte majapidamisse hoiule. Mis kohvritest edasi sai, ei ole teada. Kas võiks loota, et see väärtuslik osa Eesti Ingeri uurimusest ehk kunagi kuskilt päevavalgele tuleb?

\section{Mägiste käis Ingerimaal ka 1943. aastal}

Saksa okupatsiooni ajal korraldati Ingerimaal elavate rahvaste ümberasustamise plaane silmas pidades rahvastiku registreerimine, mille tulemustest saame teada ka Ingerimaa elanike arvu rahvaste kaupa 1943. aasta seisuga: ingerisoomlasi 62 821, isureid 8729, eestlasi 14 463, vadjalasi 667 (vt Noormets 2001: 40). Toonast Loode-Venemaa (sh Ingerimaa) rahvusvähemuste registreerimist uurinud Tiit Noormets kirjutab: „Rahvusvähemuste registreerimist Loode-Venemaal kasutas ära Tartu Ülikool, et saata sinna rahvateaduslikke 
ekspeditsioone uurimaks kohalikke eestlasi ja soome-ugri sugurahvaid. Ingerimaale lähetati terve rida juba tuntud või alles teadustegevust alustanud, kuid hiljem oma valdkonnas üldise tunnustuse saavutanud teadlasi. [---] Sügisel 1942 uurisid vadjalasi Eesti Rahva Muuseumi juhataja Erik Laid, rahvateadlased Gustav Ränk ja Ilmar Talve, keeleteadlane Paul Ariste ja kunstnik Ilmar Linnat; järgmisel suvel toimunud Ingeri uurimisreisiga liitusid ka keeleteadlased Julius Mägiste ja Felix Oinas ning antropoloog Juhan Aul" (Noormets 2001: 41-42).

Mägiste sulest ilmus nimetatud kogumistöö tulemusena vadja tekstikogumik „Woten erzählen” (Mägiste 1959), kus 225 leheküljel on avaldatud 194 teksti koguni 52 keelejuhilt. Mägiste 60. sünnipäeval iseloomustab Terho Itkonen Mägiste sõjapäevil tehtud kogumistööd järgmiselt: „Sõja-aastad ei tähendanud Mägiste jaoks töö katkemist. Tal oli võimalus talletada keelt muuhulgas mari ja mordva sõjavangidelt ning laiendada selliselt sugulaskeelte uurimist suunal, mis seni oli olnud kättesaamatu ja suletud. 1943 pääses Mägiste väiksele teaduslikule retkele Lääne-Ingeris elavate vadjalaste juurde. Nelja sealse töönädala jooksul kogunes hinnaline keelematerjal, vadja keele jaoks n-ö viimasel hetkel...." (Itkonen 1960: 7).

Mägiste töövõimele annab hinnangu ka tema kunagine õpilane ja hilisem sõber Felix Oinas, kes kirjutab talle vadja tekstide ilmumise järel 27. XI 1959 nõnda: „Sain kätte ka Sinu vadja tekstid, palju tänu! See on suur ning hoolikalt publitseeritud kogu. Pean küll imestama, et Sa nii lühikese aja jooksul, mis Sa vadja alal viibisid, sellise hulga materjali kokku kogusid. Tänu Sinu ja Ariste tööle on õnnestunud vadja keelt veel selle kustumisjärgus järelpõlvedele talletada" (KM EKLA, f 340, $\mathrm{m} 25$ : 4).

1943. aasta ekspeditsioon oli ilmselt üks neist olulistest teguritest, mis kallutasid Mägistet otsustama Eestist lahkuda, sest sedakorda pidid ka Tartu Ülikooli välitööde tegijad kandma SS-vormi. Nimetatud ekspeditsioonile pidi sõitma ka Paul Ariste, kes aga enda sõnul teeskles neeruvalu, tuli poolelt teelt tagasi ja veetis nädalapäevad haiglas, pääsedes nii Saksa sõjaväe nimekirjadesse sattumisest (Heinsoo 1995: 62; vt ka Viitso 2000: 181).

\section{Kokkuvõtteks}

Julius Mägiste teaduslik pärand on tohutu mitte ainult lehekülgede arvu, vaid ka tema poolt käsitletud uurimisteemade poolest, ulatudes murde (nt Rosona) üksikkäsitlustest tuletusõpetuse (deminutiivid), lastekeele, isikunimede ja õigekeelsusküsimusteni, läbi aegade saatis teda lemmikharrastusena etümoloogia ehk sõnade päritolu uurimine. Läänemeresoome keelte üksikküsimusi uurivates teadustöödes leidub sageli viipeid (nagu Mägiste ise ütleks) ja pöördumisi Ingerimaa või ka Ingerimaalt pärit keelekujude poole (vadja, kreevini, ingerisoome, isuri). Mägiste teenete hulka kuulub ka toonaste üliõpilaste ja hilisemate teadlaste juhatamine Ingerimaa keelte uurimise juurde. Nii näiteks meenutab Paul Ariste oma mälestusteraamatus: „Julius Mägiste oli kõige noorem õppejõud, tollal kõigest 25 -aastane. Temal oli sõbralik vahekord üliõpilastega. Ta tegi juba siis vadja keele nõnda armsaks ja lähedaseks, et ma pole tänini saanud lahti selle keele võlust" (Ariste 2008: 131). 
Mägiste kirjutas magistriväitekirja eessõnas: „Küsitav võib ju olla, kas tasub vaeva niisuguse väikese murdeala võrdlemisi detailne käsitlemine, nagu see siin, kuna ju pole puudu soome murrete üksikasjalikest esitusist, trükituist ja veel vähem käsikirjalisist. Kuid teiselt poolt on käesolev murre geograafiliselt eraldatud muist soome murdeist, liitudes väheuuritud ingeri murrete kirjusse rühma. Tähtis on, et ta võtab oma alla ainukese kitsa maakaela, mille kaudu ainuliselt soome resp. ingeri murded praegu vahetult puutuvad kokku eesti keele (Alutaguse murde) alaga, ja on viimaste vastastikuste suhete ja mõjutuste hindamise esmajärguliseks ajaliseks mõõdupuuks tuleviku täiuslikkude materjalidega arvestavale uurimistööle” (Mägiste 1925: VIII).

Tõepoolest - Julius Mägiste magistriväitekiri on jäänud tänaseni oluliseks võrdlusallikaks kõigile läänemeresoome murdeid käsitlevatele teadustöödele, toodagu näiteks naabermurrete ja -keelte ülevaated „Ingerisoome Kurgola murde fonoloogilise süsteemi kujunemine” (Leppik 1975), „Isuri keele ajalooline foneetika ja morfoloogia” (Laanest 1986), „Kirderannikumurre” (Must 1987) jt. Eesti Ingeri keelekujusid käsitlenud magistriväitekirja väärtust iseloomustatakse ka pea sajand hiljem sõnaga „igavene” (Viitso 2000: 170). Mägiste 115. sünniaastapäeval täitub „Rosona (Eesti Ingeri) murde pääjoonte” ilmumisest 90 aastat. Lõpetuseks sobiks mõte selle teadustöö teise trüki avaldamisest, sest tegemist on ainsa selle n-ö keeleliselt kadunud piirkonna, Eesti Ingeri soome ja isuri murrete tervikliku häälikuloo käsitlusega, ent kõik selle käibel olevad eksemplarid on tänaseks arvukate kasutajate lehitsemisest juba rabedaks kulunud.

\section{Allikad}

KM EKLA, f 340, m 25 : 4. A. Julius Mägiste Materjalid / Kirjad / Mägiste'le.

Käokuld... = Käokuld, Kusnetsov, Koivune. 90 aastat perekonnanimede panemisest Setomaal ja Eesti Ingeris. [Näitus.] Rahvusarhiiv. http://www.ra.ee/et/kaokuld-kusnetsov-koivune/ (1. VII 2015).

Mägiste f 52 = Tartu Ülikooli Raamatukogu, f 52, s 167. J. Mägiste elulugu, teadustööde nimestikud, retsensioonid tema tööde kohta. Kõrgemale atesteerimiskomisjonile esitatud dokumentide duplikaadid. Masinakirjas. Veebr. 1941.

\section{Kirjandus}

Ar is te, Paul 2008. Mälestusi. Toim Mart Orav. Tartu: Eesti Kirjanduse Selts.

Hein s o o, Heinike 1995. Paul Ariste ja Ingerimaa. - Minor Uralic Languages: Grammar and Lexis. Toim Ago Künnap. Tartu-Groningen: University of Tartu, University of Groningen, lk 61-66.

I t k o n e n, Terho 1960. Julius Mägiste ja hänelle omistettu „Vironseppo”. - Aamulehti, 19. XII, lk 7. [KM EKLA, f 340, m 59 : 3]

La anest, Arvo 1986. Isuri keele ajalooline foneetika ja morfoloogia. Tallinn: ENSV TA Keele ja Kirjanduse Instituut.

Leppik, Merle 1975. Ingerisoome Kurgola murde fonoloogilise süsteemi kujunemine. Tallinn: ENSV TA Keele ja Kirjanduse Instituut.

Must, Mari 1987. Kirderannikumurre. Tallinn: ENSV TA Keele ja Kirjanduse Instituut. 
Mägi s te, Julius 1922. Reisust Eesti-Ingeris. - Eesti Keel, kd I, nr 5-6, lk 156164.

Mäg i s te, Julius 1925. Rosona (Eesti Ingeri) murde pääjooned. Tartu: K.Ü. „Postimehe" trükk.

Mägist e, Julius 1928. oi-, e $i$-deminutiivid läänemeresoome keelis. Läänemeresoome nominaaltuletus I. (Acta et Commentationes Universitatis Tartuensis (Dorpatensis) B XII.2.) Tartu.

M äg i s t e, Julius 1937. Rahvuslike teaduste edust Eestis. - Looming, nr 3, lk 358$361 ; \mathrm{nr} 4$, lk 470-486.

M ä g i s t e, Julius 1959. Woten erzählen. (Suomalais-ugrilasien seuran toimituksia 118.) Helsinki: Suomalais-ugrilainen seura.

Mägist e, Julius 1972. Inkeroismurteiden sanakirja ilmestynyt. - Virittäjä, kd $76, \mathrm{nr} 4$, lk 475-478.

Noormets, Tiit 2001. Eestlaste ja teiste vähemusrahvuste ümberasustamine Loode-Venemaalt Saksa okupatsiooni ajal 1942-1943. - Tuna, nr 2, lk 39-59.

Porkka, Volmari 1885. Ueber den ingrischen Dialekt mit Berücksichtigung der übrigen finnisch-ingermanländischen Dialekte. Helsingfors.

R os en berg, Tiit 2013. Maareformist Eesti Vabariigi Virumaa Narva-tagustes valdades 1920-1940. - Õpetatud Eesti Seltsi aastaraamat 2012. Annales Litterarum Societatis Esthonicae 2012. Tartu: Õpetatud Eesti Selts, lk 129-142.

S o m m er, Samuel 1923. Perekonnanimede panemisest Naroova-tagustes valdades, Narva-Jõesuus ja Narva linnas. - Postimees, 13. VIII, nr 212, lk 4.

Vi it s o, Tiit-Rein 2000. Julius Mägiste keeleteadlasena. - Julius Mägiste 100. (TÜ eesti keele õppetooli toimetised 15.) Koost Valve-Liivi Kingisepp. Tartu: Tartu Ülikool, lk 167-181.

\section{Julius Mägiste as a researcher of the Finnic dialects spoken in Estonian Ingermanland}

Keywords: Julius Mägiste, Estonian Ingermanland, Ingrian Finnish language, Ingrian language

December 19, 2015 is the $115^{\text {th }}$ anniversary of the birth of Estonian linguist Julius Mägiste. One of the earliest scholarly studies by Mägiste was his Master's thesis Rosona (Eesti Ingeri) murde pääjooned („The main features of Rosona (Estonian Ingermanland) dialect"), defended in 1923 and published in 1925, which provides a systematic survey of two dialects spoken in the western part of Ingermanland. The linguists of the time did not consider Ingrian a separate language, but rather classified it among Finnish dialects. In his study Mägiste has grouped the dialects discussed in his thesis by the religious affiliation of the speakers, namely, Lutherans are soomlased 'Finns', while the Greek Catholics are ingrikud ehk isurlased 'Ingrians, or Izhorians'. The press and officials of the new Estonian Republic were not particularly consistent in their reference to the inhabitants of Estonian Ingermanland either. In order to collect material for his Master's thesis Mägiste conducted fieldwork in Estonian Ingermanland in 1922, supported by an allowance from the Mother Tongue Society. He replenished his collection in the spring and August of 1923. A survey of Mägiste's first trip to the region was published in the journal Eesti Keel in 1922, and this was his first publication. 
Beside the language situation in Estonian Ingermanland he also touched upon the local educational and cultural life. At the early age of 28 Mägiste was elected Extraordinary Professor of Finnic Languages of the University of Tartu, on which occasion his scientific contribution, including his Master's thesis was highly commended by his proponents Lauri Kettunen, Julius Mark and Andrus Saareste.

In 1937, Mägiste finished a 250-page manuscript of West-Ingrian texts with a glossary, but it was not published. Furthermore, the manuscript fell victim to WW II and it remains lost to this day. Although numerous later publications by Mägiste often contain examples from the language varieties used in Estonian Ingermanland, his Master's thesis was the first and last special study devoted to the Ingrian dialects spoken in Estonia.

Eva Saar (b. 1976), MA, University of Tartu, doctoral student, researcher of language history, eva.saar@ut.ee 